Article

\title{
Enhanced oxygen reduction reaction performance over Pd catalysts by oxygen-surface-modified $\mathrm{SiC}$
}

\author{
Jing Li a, Xiang Sun ${ }^{b}$, Yongzheng Duan a, Dongmei Jia a, Yuejin Li a,b, Jianguo Wang b,* \\ a College of Chemical Engineering and Safety, Binzhou University, Binzhou 256603, Shandong, China \\ b Institute of Industrial Catalysis, College of Chemical Engineering, State Key Laboratory Breeding Base of Green-Chemical Synthesis Technology, Zhejiang \\ University of Technology, Hangzhou 310032, Zhejiang, China
}

\section{A R T I C L E I N F O}

\section{Article history:}

Received 28 July 2020

Accepted 14 September 2020

Available online 22 November 2020

\section{Keywords:}

Silicon carbide

Surface oxidization

Oxygen reduction reaction

Density functional theory

Charge transfer

Electron-rich Pd

\begin{abstract}
A B S T R A C T
Obtaining a detailed understanding of the surface modification of supports is crucial; however, it is a challenging task for the development and large-scale fabrication of supported electrocatalysts that can be used as alternatives to Pt-based catalysts for the oxygen reduction reaction (ORR). In this study, commercial silicon carbide ( $\mathrm{SiC}$ ) was modified through surface oxidization (O-SiC) to support the use of Pd nanoparticles (Pd NPs) as electrocatalysts for ORR. The obtained Pd/O-SiC catalysts exhibited better ORR activity, stronger durability, and higher resistance to methanol poisoning than that exhibited by commercial Pt/C. The role of the support in enhancing the ORR performance, especially the oxidization of $\mathrm{SiC}$ surfaces, was discussed in detail based on the experimental characterizations and density functional theory calculations. The underlying mechanism of the superior ORR performance of $\mathrm{Pd} / \mathrm{O}-\mathrm{SiC}$ catalysts was attributed to the charge transfer from $\mathrm{SiC}_{x} \mathrm{O}_{y}$ to $\mathrm{Pd}$ NPs on the surfaces of $\mathrm{SiC}$ and the strong metal-support interactions (SMSIs) between $\mathrm{Pd}$ and $\mathrm{SiC}_{x} \mathrm{O}_{y}$. The charge transfer enhanced the ORR activity by inducing electron-rich Pd, increased the adsorption of the key intermediate $\mathrm{OOH}$, and decreased the Gibbs free energy of the critical ORR step. Furthermore, SMSIs enhanced the ORR stability of the Pd/O-SiC catalyst. This study provided a facile route for designing and developing highly active Pd-based ORR electrocatalysts.
\end{abstract}

(C) 2021, Dalian Institute of Chemical Physics, Chinese Academy of Sciences. Published by Elsevier B.V. All rights reserved.

\section{Introduction}

Fuel cells have attracted significant research interest as clean energy technology owing to their high efficiency and low emissions [1-4]. Pt/C is used as a cathodic oxygen reduction reaction (ORR) catalyst in state-of-the-art fuel cells [1,5-7]. However, the high cost, limited Pt reserves, and low stability of commercial Pt/C hinder their widespread use in fuel cells $[8,9]$. Thus, new strategies are needed to develop Pt-free ORR catalysts. The electron structure and chemical properties of Pd are similar to those of Pt; however, Pd reserves are 50 times higher than Pt reserves [10]. Moreover, Pd has an excellent resistance against methanol and carbon monoxide poisoning [11]. These characteristics make $\mathrm{Pd}$ a promising alternative to $\mathrm{Pt}$ in ORR catalysts. However, the ORR activity of commercial Pd/C catalysts is lower than that of the commercial Pt/C. Therefore, several research have focused on improving the activity of Pd-based ORR catalysts.

Enhancing the ORR activity of Pd-based catalysts has two aspects. One aspect involves the alloying of Pd with transition

\footnotetext{
* Corresponding author. Tel/Fax: +86-571-88871037; E-mail: jgw@zjut.edu.cn

This work was supported by the National Natural Science Foundation of China (51808040), Zhejiang Province Science and Technology Innovation Team (2017R5203), and Scientific Research Project of Binzhou University (2019Y17).

DOI: 10.1016/S1872-2067(20)63716-0 | http://www.sciencedirect.com/science/journal/18722067 | Chin. J. Catal., Vol. 42, No. 6, June 2021
} 
metals, such as Co [12,13], Fe [13,14], $\mathrm{Au}[8,15], \mathrm{Cu}[8,15,16]$, Ni $[1,17,18]$, Mo [19], and W [20]. However, bimetallic or polymetallic electrocatalysts often suffer from undesirable performance owing to the limited interaction between different components [1]. The other aspect is to load Pd on various supports [21-24] that are not based on carbon. Carbon corrosion experienced by carbon supports during fuel cell operation under harsh conditions leads to the migration and agglomeration of catalyst particles, induces the loss of catalytic activity, and decreases the durability of cells $[4,25,26]$. Some alternative support materials enhance the stability of catalysts. Our previous work [22] showed that after loading Pd NPs on $\mathrm{TiO}_{2}$ modified with oxygen vacancies $\left(\mathrm{TiO}_{2}-\mathrm{V}_{0}\right)$, strong metal-support interactions (SMSIs) between Pd NPs and $\mathrm{TiO}_{2}-\mathrm{V}_{0}$ occurred and changed the electronic structure of Pd NPs [27]. The electron-rich Pd obtained through electron transfer from the support to Pd NPs exhibits excellent ORR activity. However, the complex $\mathrm{TiO}_{2}-\mathrm{V}_{0}$ preparation and weak charge transfer from $\mathrm{TiO}_{2}-\mathrm{V}_{0}$ to $\mathrm{Pd}$ NPs limit the widespread application of $\mathrm{Pd} / \mathrm{TiO}_{2}-\mathrm{V}_{0}$ catalysts. Therefore, it is necessary to develop strong electron-donating supports by applying a simple fabrication method to tune the electronic structure of $\mathrm{Pd}$ and further improve the ORR performance.

Previously reported studies [28-30] have demonstrated that $\mathrm{SiO}_{2}$ supplies electrons to $\mathrm{Pd}$ that generates electronegative $\mathrm{Pd}$ when $\mathrm{Pd}$ is loaded onto $\mathrm{SiO}_{2}$. Our previous work [21] showed that $\mathrm{SiO}_{2}$ enhanced the ORR activity in an alkaline solution; however, the ORR stability was poor. Compared with $\mathrm{SiO}_{2}$, $\mathrm{SiC}$ has an electron-donating activity similar to that of metal NPs [31] and higher chemical and electrochemical durability [32-36]. Thus, SiC has attracted considerable attention as a catalyst support in fuel cells in recent years [32,33,37,38]. The interaction between metals and $\mathrm{SiC}$ was weak [36,39]; therefore, $\mathrm{SiC}$ with specific morphologies [40] or with modified surfaces (oxidization [39,41,42] or Ti coating [38]) were synthesized to anchor metal NPs and to enhance physical or chemical interactions. However, the preparation of these SiC-based supports was either complex or costly. Surface oxidization of SiC during preparation, preservation, or application under aerobic conditions was inevitable [33]. The above analysis indicates that $\mathrm{SiC}$ with oxygenic groups on their surfaces generated under mild conditions are promising supports for Pd-based ORR catalysts owing to their facile and large-scale preparation and strong interaction with metals. To the best of our knowledge, the effect of oxygenic groups, which are present on SiC surfaces, on the ORR performance has not been investigated yet. Hence, a detailed investigation on the effects of these oxygenic groups on ORR is essential for understanding, designing, and developing SiC-supported catalysts with excellent ORR performance.

In this study, Pd NPs were loaded onto O-SiC using a simple deposition precipitation method. The ORR performance of the $\mathrm{Pd} / \mathrm{O}-\mathrm{SiC}$ catalysts in a solution $(0.1 \mathrm{~mol} / \mathrm{L} \mathrm{KOH})$ was superior than that of the commercial Pt/C. By combining experiments with density functional theory (DFT) calculations, the underlying mechanism for achieving excellent ORR activity of Pd/O-SiC was revealed. The excellent ORR activity of $\mathrm{Pd} / \mathrm{O}-\mathrm{SiC}$ was ascribed to the charge transfer from O-SiC to Pd NPs. The SMSIs between the Pd NPs and O-SiC improved the stability of the catalysts.

\section{Experimental section}

\subsection{Materials}

$\mathrm{SiC}(99.9 \%, 40 \mathrm{~nm}), \mathrm{PdCl}_{2}$ (>99\%), KOH (analytical purity), and $\mathrm{NaBH}_{4}$ (analytical purity) were purchased from Sigma-Aldrich. Commercial Pt/C (20 wt\% Pt) and Pd/C (10 wt\% Pd) were obtained from Alfa Aesar. The reagents were used without further purification.

\subsection{Preparation of $\mathrm{Pd} / \mathrm{O}$-SiC catalysts}

Pd/O-SiC was synthesized using a modified deposition precipitation method [21]. First, $\mathrm{SiC}\left(40 \mathrm{mg}\right.$ ) and $\mathrm{PdCl}_{2}$ (a calculated mass) powders were dispersed in $10 \mathrm{~mL}$ of deionized water in a round-bottomed flask via ultrasonication for $30 \mathrm{~min}$. Subsequently, a $\mathrm{KOH}$ solution ( $1 \mathrm{~mol} / \mathrm{L}$ ) was added dropwise to the $\mathrm{PdCl}_{2}-\mathrm{SiC}$ solution until $\mathrm{pH}$ reached 10 . Then, $\mathrm{NaBH}_{4}$ was added as a reductant and the mixture was magnetically stirred for $1 \mathrm{~h}$. Finally, the product was obtained after filtering, washing, and drying overnight in a vacuum oven at $60{ }^{\circ} \mathrm{C}$. The obtained products with different Pd loadings were labeled in accordance with X-ray photoelectron spectroscopy (XPS) results (Table S2) as $1.0 \mathrm{wt} \% \mathrm{Pd} / \mathrm{O}-\mathrm{SiC}, 1.8 \mathrm{wt} \% \mathrm{Pd} / \mathrm{O}-\mathrm{SiC}$, and 2.5 wt $\% \mathrm{Pd} / \mathrm{O}-\mathrm{SiC}$. Unless stated otherwise, $\mathrm{Pd} / \mathrm{O}-\mathrm{SiC}$ indicates the $2.5 \mathrm{wt} \% \mathrm{Pd} / \mathrm{O}-\mathrm{SiC}$ catalyst.

\subsection{Material characterization}

Sample morphologies were observed using transmission electron microscopy (TEM, Tecnai G2F30S-Twin) at $300 \mathrm{keV}$. High-angle annular dark-field scanning TEM and energy-dispersive X-ray (EDX) spectroscopy analyses were conducted with a FEI Titan G2 80-200 ChemiSTEM. The powder X-ray diffraction (XRD) patterns of the samples were obtained using an X-ray diffractometer (Xpert-Pro) with $\mathrm{Cu} K_{\alpha}$ radiation $(\lambda=1.5418 \AA)$ at $40 \mathrm{kV}$. XPS data were recorded on an X-ray photoelectron spectrometer (Thermo Scientific ESCALAB250Xi) equipped with an $\mathrm{Al} K_{\alpha} \mathrm{X}$-ray radiation source.

\subsection{Electrochemical measurements}

The ORR catalyst performance tests were conducted using a ring-disk electrode (RDE) connected to a CHI760D electrochemical analyzer ( $\mathrm{CH}$ Instruments) in $\mathrm{O}_{2}$-saturated $0.1 \mathrm{M} \mathrm{KOH}$ electrolyte media at room temperature. The standard three-electrode system consisted of a glassy carbon electrode (GC, $4.0 \mathrm{~mm}$ in diameter) with the catalyst as the working electrode, $\mathrm{Pt}$ wire as the counter electrode, and $\mathrm{Ag} / \mathrm{AgCl}(\mathrm{KCl}, 3 \mathrm{M})$ as the reference electrode. All potentials vs. the $\mathrm{Ag} / \mathrm{AgCl}$ electrode were calibrated against the reversible hydrogen electrode (RHE) using the following equation: $E$ (RHE) = $\mathrm{E}(\mathrm{Ag} / \mathrm{AgCl})+0.197 \mathrm{~V}+0.059 \times \mathrm{pH}$. To prepare the working electrode, $4.0 \mathrm{mg}$ of catalyst and $1.6 \mathrm{mg}$ of Vulcan XC-72R car- 
bon (Cabot Corporation, a conducting reagent) were first added to a mixture containing $100 \mu \mathrm{L}$ of Nafion (5 wt\%) solution and $900 \mu \mathrm{L}$ of absolute ethanol. Then, the mixture was ultrasonicated for 30 min to obtain the catalyst ink. Finally, $5 \mu \mathrm{L}$ of homogeneous black ink was uniformly dropped on the GC electrode and dried at room temperature. The working electrode for electrochemical tests was thus obtained.

Cyclic voltammograms (CV) curves of the catalysts were recorded over the potential range of $0-1.2 \mathrm{~V}$ (vs. RHE) at room temperature using a $\mathrm{O}_{2}$-saturated $0.1 \mathrm{M} \mathrm{KOH}$ solution at a scan rate of $100 \mathrm{mV} \mathrm{s}^{-1}$. Linear sweep voltammetry (LSV) measurements were conducted in the same range as the CV tests with a sweep rate of $20 \mathrm{mV} \mathrm{s}^{-1}$ and at different rotation rates (400, $625,900,1225,1600$, and $2025 \mathrm{rpm}$ ). Electrochemical impedance spectroscopy (EIS) analyses were performed at frequencies from $10^{6} \mathrm{~Hz}$ to $1 \mathrm{~Hz}$ with an amplitude of $5 \mathrm{mV}$. The tolerance of the catalysts to methanol was evaluated through current (i)-time $(t)$ chronoamperometry at $0.5 \mathrm{~V}_{\mathrm{RHE}}$ with the addition of $2 \mathrm{~mL}$ methanol to $\mathrm{KOH}$ electrolyte. The stability of ORR catalysts was also measured through $i$ - $t$ chronoamperometry at $0.5 \mathrm{~V}_{\mathrm{RHE}}$ without the presence of methanol.

Rotating RDE (RRDE) voltammogram measurements were performed using the same procedures as those used for RDE. Hydrogen peroxide yield $\left(\mathrm{HO}_{2}-\%\right)$ and electron-transfer number $(n)$ were calculated using the following equations [43]:

$$
\begin{gathered}
n=4 I_{d} /\left(I_{d}+I_{d} / \mathrm{N}\right), \\
H O_{2}^{-} \%=200 \times \frac{I_{r} / \mathrm{N}}{I_{d}+\frac{I_{r}}{\mathrm{~N}}},
\end{gathered}
$$

where $I_{d}$ is the disk current, $I_{r}$ is the ring current, and $N$ represents the $\mathrm{H}_{2} \mathrm{O}_{2}$ collection coefficient (0.39) at the Pt ring.

\subsection{Computational methods}

DFT calculations were conducted using the Vienna $a b$ initio simulation package [22], and projector augmented wave potentials were applied [44-46]. XRD and XPS results suggested that the SiC support was $\beta$-SiC with an exposed (111) crystal plane and surface oxygen coverage of approximately $20 \%$. Thus, $\beta$-SiC (111) with and without $20 \%$ surface oxygen coverage were used as the $\mathrm{SiC}$ and $\mathrm{O}-\mathrm{SiC}$ models, respectively. The graphene model was used to represent the carbon materials, and the $\mathrm{Pd}_{4}$ cluster was used to represent the Pd NPs. The $\beta$-SiC (111) surface was modeled using periodic slabs of two bilayers with the bottom bilayer fixed. The $(4 \times 4) \mathrm{SiC}(111)$ surface unit cell was set with lattice constants $(\mathrm{a}=12.39 \AA \mathrm{A}, \mathrm{b}=12.39 \AA$, and $\mathrm{c}=23.22 \AA$ ). The $\mathrm{Pd}_{4}$ cluster was loaded on various support models with optimized structures. Brillouin zone integration was conducted with a $4 \times 4 \times 1 \mathrm{k}$-point, and the convergence criteria of the force and energy were $10 \mathrm{meV}^{-1}$ and $0.01 \mathrm{meV}$, respectively.

\section{Results and discussion}

Schematic of the preparation of Pd/O-SiC catalysts is shown in Scheme 1.

The morphologies of $\mathrm{O}-\mathrm{SiC}$ and $\mathrm{Pd} / \mathrm{O}-\mathrm{SiC}$ were observed with TEM, as shown in Figs. 1 and S1. Pd NPs with a mean di-

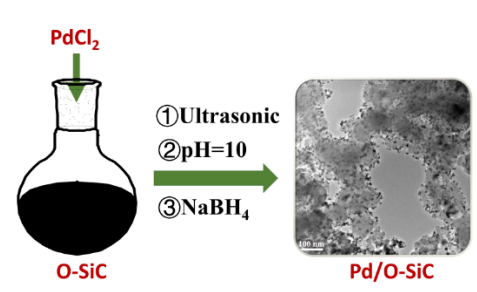

Scheme 1. Synthesis of Pd/O-SiC.

ameter of $5.2 \mathrm{~nm}$ were well dispersed over the 0-SiC support, and no apparent agglomeration of Pd NPs was observed in the TEM image of Pd/O-SiC (Fig. 1(a)). As shown in Fig. 1(b), the lattice fringes of the Pd NPs clearly exhibited a lateral spacing of $0.225 \mathrm{~nm}$, which matched well with those exhibited by the Pd (111) crystal planes. The chemical composition and elemental dispersion of $\mathrm{Pd} / \mathrm{O}-\mathrm{SiC}$ were determined using EDX mapping analysis (Figs. 1(c)-(h)). The results indicated that four well-distributed elements ( $\mathrm{Si}, \mathrm{C}, \mathrm{O}$, and $\mathrm{Pd}$ ) were present in the $\mathrm{Pd} / \mathrm{O}-\mathrm{SiC}$ catalyst. The distribution of $\mathrm{O}$ was consistent with that of $\mathrm{Si}$ and $\mathrm{C}$ and was caused by the uniform oxidization of the $\mathrm{SiC}$ surface.

The XRD patterns of $\mathrm{O}-\mathrm{SiC}$ and $\mathrm{Pd} / \mathrm{O}-\mathrm{SiC}$ with various $\mathrm{Pd}$ loadings are shown in Fig. 2(a). The peaks at $35.7^{\circ}, 60.0^{\circ}$, and $72.0^{\circ}$ in the XRD pattern of O-SiC were assigned to the SiC (111), (220), and (311) lattice planes (JCPDS, 01-1119), respectively. A small shoulder observed for the $\mathrm{SiC}$ support at $33.6^{\circ}$ was related to the characteristic stacking faults in $\beta$-SiC [35]. When the Pd NPs were supported on O-SiC, the peaks of O-SiC remained unchanged most likely because of the excellent physical and chemical stabilities of $\mathrm{SiC}$ [47]. No Pd peaks were observed in the XPS pattern of $1.0 \mathrm{wt} \% \mathrm{Pd} / \mathrm{O}-\mathrm{SiC}$ because of the high dispersion of the Pd NPs and low Pd loading [31]. Two peaks at $40.1^{\circ}$ and $46.7^{\circ}$ that appeared at $1.8 \mathrm{wt} \%$ Pd loading corresponded to Pd (111) and Pd (200) facets, respectively, and their intensity increased with an increase in the Pd content. The presence of $\mathrm{Pd}(111)$ in $2.5 \mathrm{wt} \% \mathrm{Pd} / \mathrm{O}-\mathrm{SiC}$ further confirmed the TEM result (Fig. 1(b)). The absence of characteristic $\mathrm{SiO}_{2}$ diffraction peaks in the XRD patterns of the O-SiC support and Pd/O-SiC catalysts (Fig. 2(a)) was ascribed to the amorphous $\mathrm{SiO}_{2}$ film that was only formed on the $\mathrm{SiC}$ surfaces at room temperature[39] and the low $\mathrm{SiO}_{2}$ content of the monolithic substrate.

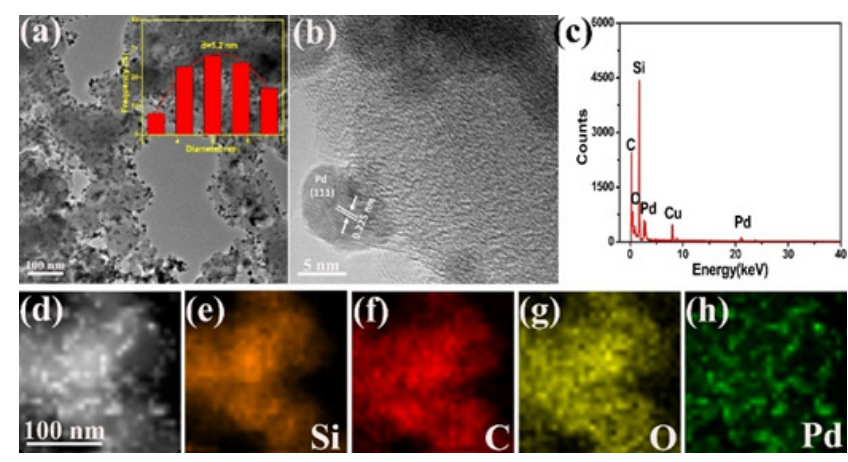

Fig. 1. TEM characterization of the Pd/O-SiC catalyst. (a) TEM image (inset: Pd particle size in the Pd/O-SiC catalyst); (b) HRTEM image; (c) EDX pattern; (d-h) EDS elemental mapping images of $\mathrm{Si}, \mathrm{C}, \mathrm{O}$, and $\mathrm{Pd}$ in Pd/O-SiC. 

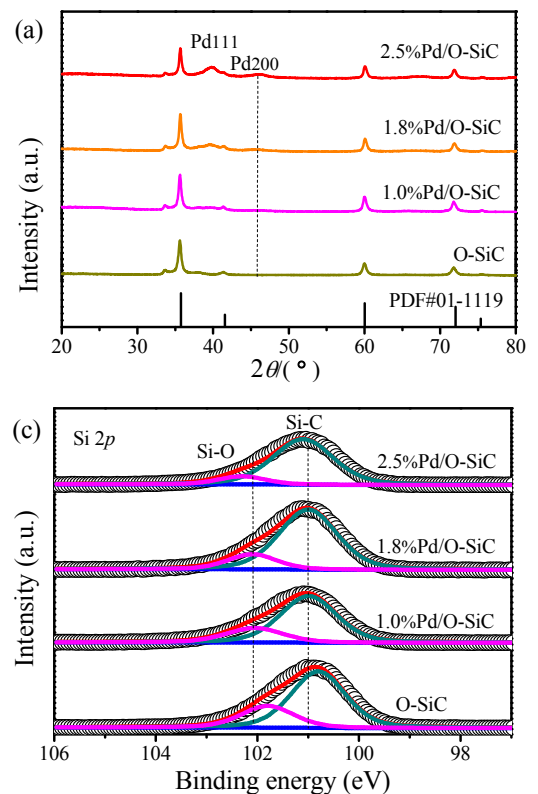
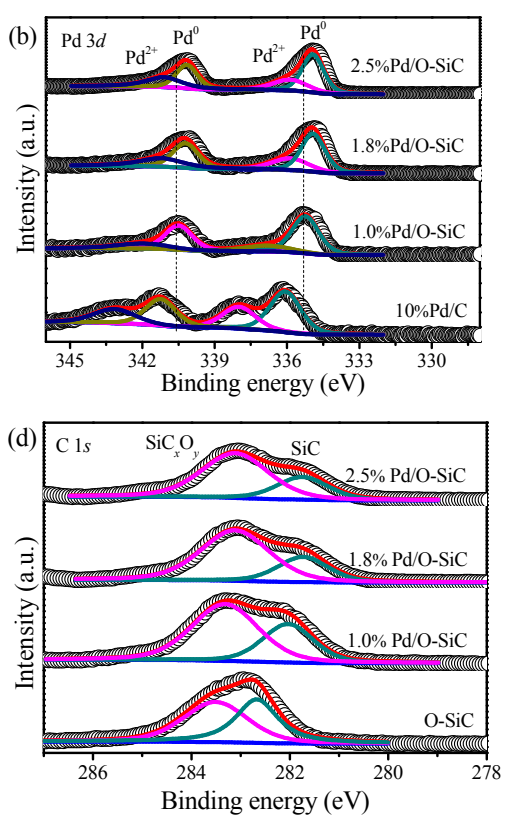

Fig. 2. XRD and XPS characterizations of catalysts. (a) XRD patterns; (b) Pd 3d; (c) Si 2p; (d) C $1 s$ XPS high-resolution spectra of O-SiC and Pd/O-SiC with various Pd loadings.

XPS data were collected to investigate the interaction between the Pd NPs and the O-SiC support. The chemical states of $\mathrm{Pd}, \mathrm{Si}$, and $\mathrm{C}$ in $\mathrm{Pd} / \mathrm{O}-\mathrm{SiC}$ were detected, as shown in Figs. 2(b)-(d). The Pd $3 d$ peaks of the $\mathrm{Pd} / \mathrm{O}-\mathrm{SiC}$ and $\mathrm{Pd} / \mathrm{C}$ catalysts are shown in Fig. 2(b). The peaks of $\mathrm{Pd} / \mathrm{C}$ at 336.07 and 341.24 $\mathrm{eV}$ were assigned to metallic $\mathrm{Pd}$, whereas the other two peaks at 337.99 and $343.15 \mathrm{eV}$ were attributed to PdO [21] originating from the partial reoxidation of metallic $\mathrm{Pd}$ by $\mathrm{O}_{2}$ or $\mathrm{H}_{2} \mathrm{O}$ when the catalyst was exposed to air [48]. The comparison of $\mathrm{Pd} 3 d$ spectra with the $\mathrm{Pd} / \mathrm{C}$ catalyst revealed that the peaks of metallic Pd and PdO in Pd/O-SiC significantly shifted to a lower binding energy, and the shift became increasingly noticeable with an increase in the Pd loading. These results clearly indicated that $\mathrm{O}-\mathrm{SiC}$ donated more electrons to $\mathrm{Pd}$ than $\mathrm{C}$, and the charge transfer from the O-SiC support to the Pd surface affected the electronic structures of the Pd NPs [49]. In the Si $2 p$ spectra of the O-SiC support (Fig. 2(c)), the two peaks at 100.8 and $101.8 \mathrm{eV}$ were assigned to $\mathrm{Si}-\mathrm{C}$ and Si-O [35], respectively. $\mathrm{Si}-\mathrm{O}$ was formed because of the surface oxidation of $\mathrm{SiC}$; this interpretation was consistent with the TEM results (Fig. 1). The ratio of $\mathrm{Si}-\mathrm{O}$ to $\mathrm{Si}-\mathrm{C}$ decreased after Pd was loaded onto O-SiC (Fig. 2(c)). This reduction corresponded to the instability of $\mathrm{SiO}_{2}$ in the $\mathrm{KOH}$ solution. The gradual shift of the $\mathrm{Si} 2 p$ peak position to a higher binding energy (up to $0.2 \mathrm{eV}$ ) with an increase in the Pd loading was ascribed to the lower electronegativity of $\mathrm{Si}$ than that of $\mathrm{Pd}, \mathrm{Si}, \mathrm{C}$, and $\mathrm{O}$ elements and agreed well with the previously reported results [50]. Fig. 2(d) shows the C $1 s$ spectra of O-SiC and Pd/O-SiC. The two peaks at 282.7 and $283.5 \mathrm{eV}$ of $\mathrm{O}-\mathrm{SiC}$ corresponded to $\mathrm{SiC}$ and $\mathrm{SiC}_{x} \mathrm{O}_{y}$ [50], respectively, and the intensity of the $\mathrm{SiC}_{x} \mathrm{O}_{y}$ peaks increased after $\mathrm{Pd}$ deposition (Table $\mathrm{S} 1$ ). $\mathrm{SiC}_{x} \mathrm{O}_{y}$ originate from the surface oxidation of the $\mathrm{SiC}$ support, as mentioned previously. SiC was further oxidized when Pd NPs were loaded on O-SiC in alkaline solution. The further oxidation of $\mathrm{SiC}$ in alkaline solution was confirmed by analyzing the $\mathrm{O}$ content (Table S2). The formation of $\mathrm{SiC}_{x} \mathrm{O}_{y}$ was beneficial for anchoring $\mathrm{Pd}$ and enhancing the stability of Pd NPs [32].

XPS analysis indicated that $\mathrm{C}$ and $\mathrm{O}-\mathrm{SiC}$ supports have different effects on the electronic structures of the Pd NPs. These effects were further explored using DFT calculations (Fig. 3). The Bader charge and charge density difference analysis of $\mathrm{Pd}_{4}$ supported on $\mathrm{O}-\mathrm{SiC}$ and $\mathrm{C}$ indicated opposite charge transfer directions in $\mathrm{Pd}_{4} / \mathrm{O}-\mathrm{SiC}$ and $\mathrm{Pd}_{4} / \mathrm{C}$. The Bader charge analysis showed that the total electron transfer from $\mathrm{O}-\mathrm{SiC}$ and $\mathrm{C}$ to $\mathrm{Pd}_{4}$ was -0.22 and 0.21 e (Figs. 3(c)-(d)), respectively, further proving the XPS results (Fig. 2(b)). The binding energy of $\mathrm{Pd}_{4}$ on $\mathrm{O}-\mathrm{SiC}$ was considerably higher than that on $\mathrm{C}(-9.92 \mathrm{eV} v s$. $-1.08 \mathrm{eV}$ ) (Figs. 3(c)-(d)), and the induced SMSIs were beneficial for improving the stability of the catalyst [51].

The ORR performance of $\mathrm{Pd} / \mathrm{O}-\mathrm{SiC}$ was compared with that of the commercial Pt/C, Pd/C, and O-SiC. Fig. 4(a) shows the CV curves of these catalysts. The O-SiC support exhibited poor ORR

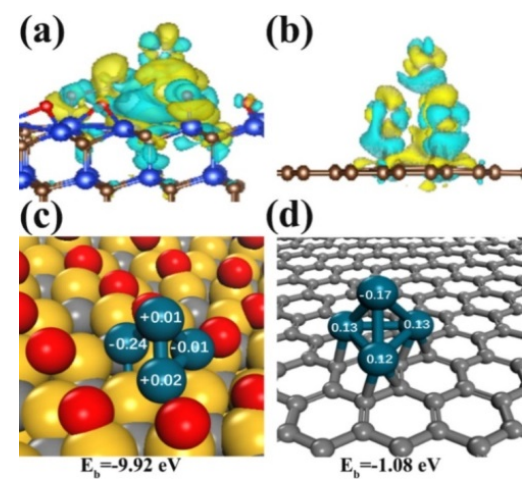

Fig. 3. Electronic structures of $\mathrm{Pd} / \mathrm{O}-\mathrm{SiC}$ and $\mathrm{Pd} / \mathrm{C}$. Charge density difference, binding energies, and Bader charge of $\mathrm{Pd}_{4}$ supported on O-SiC $(a, c)$ and graphene $(b, d)$. The blue and yellow areas in Fig. 3(a)-(b) represent negative and positive charges, respectively. 
activity with an onset potential of $0.72 \mathrm{~V}_{\text {RHE }}$. When Pd NPs were loaded onto the O-SiC support, the onset potential of the $\mathrm{Pd} / \mathrm{O}-\mathrm{SiC}$ catalyst exhibited a positive shift because of the good ORR activity of the Pd noble metal [4,52]. Compared with commercial $\mathrm{Pd} / \mathrm{C}, \mathrm{Pd} / \mathrm{O}-\mathrm{SiC}$ displayed a higher positive onset and half-wave potentials, which indicated that the support played a critical role in enhancing the ORR activity. Moreover, the onset and half-wave potentials of $\mathrm{Pd} / \mathrm{O}-\mathrm{SiC}$ improved even further than those of the commercial $\mathrm{Pt} / \mathrm{C}$. The results indicated that the ORR activity of $\mathrm{Pd} / \mathrm{O}-\mathrm{SiC}$ was better than that of the commercial Pt/C because of the electron-rich Pd induced by the charge transfer from O-SiC to Pd NPs $[21,22]$. The LSV responses of the catalysts are shown in Fig. 4(b), and they were used to confirm the ORR activity. Pd/O-SiC exhibited onset and half-wave potentials of 0.97 and $0.86 \mathrm{~V}_{\mathrm{RHE}}$, respectively. The values indicated that $\mathrm{Pd} / \mathrm{O}-\mathrm{SiC}$ outperformed the commercial $\mathrm{Pt} / \mathrm{C}$, and they were superior to those of O-SiC $(0.72$ and 0.61 $\mathrm{V}_{\mathrm{RHE}}$ ) and the commercial Pd/C (0.95 and 0.78 $\mathrm{V}_{\mathrm{RHE}}$ ). The ORR activity of Pd/O-SiC was also significantly better than those of many previously reported Pd-based catalysts in alkaline electrolytes (Table S3).

The transferred electron number $(n)$ of ORR was obtained using the K-L equation and RRDE experiment was conducted to understand the mechanism of the ORR process in more detail (Figs. 4(c)-(d)). As shown in Fig. 4(c), the RDE curves of $\mathrm{Pd} / 0-\mathrm{SiC}$ obtained at various rotation rates (400-2500 rpm) were analyzed using the K-L equation [22]. The $n$ value was approximately 4.0 above the range of $0.50 \mathrm{~V}_{\mathrm{RHE}}$ to $0.65 \mathrm{~V}_{\mathrm{RHE}}$, indicating a $4 \mathrm{e}$ transfer mechanism [53]. RRDE experiment was further conducted (Fig. 4(d)) to identify the ORR mechanism, as indicated before. The $\mathrm{H}_{2} \mathrm{O}_{2}$ yield was close to 0 , and the $n$ value per $\mathrm{O}_{2}$ molecule was approximately 4.0 in the potential range of 0-0.8 $\mathrm{V}_{\text {RHE. }}$ These results were in accordance with those obtained using the K-L equation, which indicated that $\mathrm{H}_{2} \mathrm{O}_{2}$ formation was negligible and $\mathrm{O}_{2}$ was directly reduced to $\mathrm{H}_{2} \mathrm{O}$ on the Pd/O-SiC catalyst [54].

The ORR kinetics of the catalysts were explored using the Tafel slopes calculated for the polarization curves at $1600 \mathrm{rpm}$ (Fig. 4(e)). The Tafel slope (83 $\mathrm{mV} \mathrm{dec}^{-1}$ ) of Pd/O-SiC was much

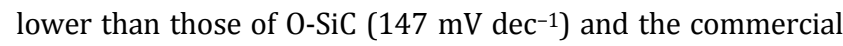
$\mathrm{Pd} / \mathrm{C}\left(115 \mathrm{mV} \mathrm{\textrm {dec } ^ { - 1 }}\right)$ and was comparable to that of the commercial Pt/C (80 $\left.\mathrm{mV} \mathrm{dec}^{-1}\right)$. The low Tafel slope indicated the fast ORR kinetics of Pd/O-SiC in alkaline electrolytes [55]. EIS characterization was also performed to further illustrate the charge transfer properties of the catalysts. The Nyquist plots obtained with EIS clearly showed that Pd/O-SiC presented a lower real axis intercept and smaller high-frequency semicircles than Pd/C and O-SiC (Fig. S2). These results indicated the lower electron-transfer impedance of $\mathrm{Pd} / \mathrm{O}-\mathrm{SiC}$ and further confirmed that $\mathrm{Pd} / \mathrm{O}-\mathrm{SiC}$ improved the electron transfer between the Pd/O-SiC interface and electrolyte [56,57].

The methanol oxidation tolerance of $\mathrm{Pd} / \mathrm{O}-\mathrm{SiC}$ and $\mathrm{Pt} / \mathrm{C}$ is shown in the inset of Fig. 4(f). When methanol was introduced into the $\mathrm{KOH}$ electrolyte, no clear change in the current density of Pd/O-SiC was observed, whereas the Pt/C catalyst exhibited a significant current drop. These results suggested that $\mathrm{Pd} / \mathrm{O}-\mathrm{SiC}$ possessed strong resistance against the methanol crossover effect [58]. The stability of the catalysts was also evaluated through $i-t$ chronoamperometry experiments (Fig. 4(f)). Pd/O-SiC achieved a high current retention of $96.5 \%$, (a)

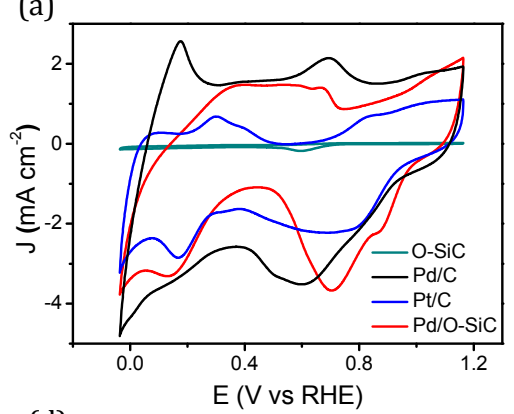

(d)

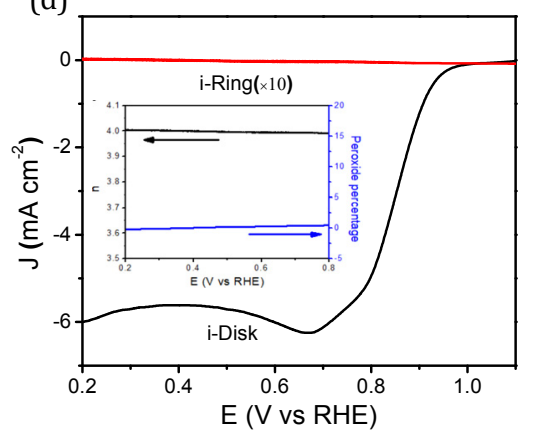

(b)

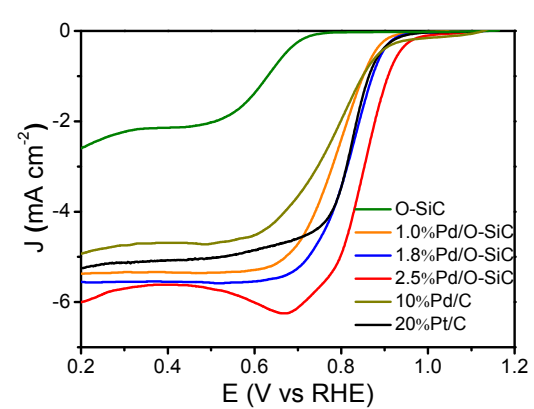

(e)

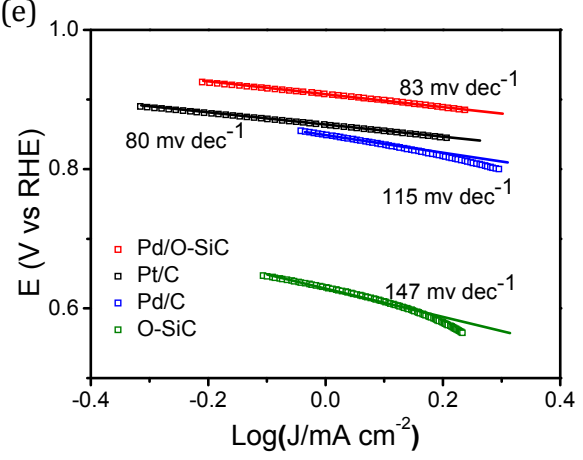

(c)

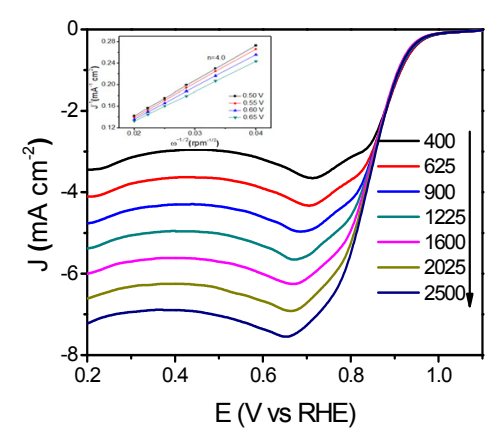

(f)

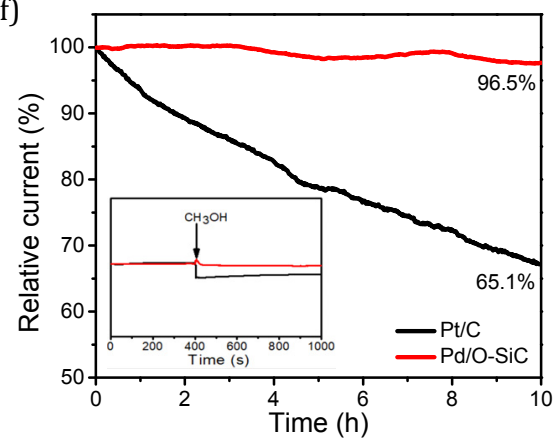

Fig. 4. Electrochemical analysis of catalysts. (a) CV results for $\mathrm{Pd} / \mathrm{O}-\mathrm{SiC}, \mathrm{O}-\mathrm{SiC}, \mathrm{Pd} / \mathrm{C}$, and $\mathrm{Pt} / \mathrm{C}$ catalysts in $\mathrm{O}_{2}$-saturated $0.1 \mathrm{M} \mathrm{KOH}$ solution obtained with a scan rate of $100 \mathrm{mV} \mathrm{s}^{-1}$. (b) ORR polarization curves of different catalysts acquired at $1600 \mathrm{rpm}$. The potential scan rate was $20 \mathrm{mV} \mathrm{s}{ }^{-1}$. (c) Rotation-rate-dependent voltammograms of Pd/O-SiC in 0.1 M KOH solution at 400-2500 rpm. The inset shows the K-L plots of the Pd/O-SiC catalyst. (d) RRDE measurements (1600 rpm) of Pd/O-SiC (inset: Electron-transfer numbers and peroxide percentage of the Pd/O-SiC electrode). (e) Tafel plots of Pd/O-SiC, O-SiC, Pd/C, and Pt/C catalysts. (f) Chronoamperometric responses for ORR at Pd/O-SiC and Pt/C electrodes. The inset shows the comparison of the methanol oxidation tolerance of Pd/O-SiC and Pt/C at $0.50 \mathrm{~V}_{\text {RHE. }}$ 
whereas Pt/C displayed a considerable current loss of $34.9 \%$. An accelerated durability test was also conducted to assess the stability of the Pd/O-SiC catalyst. Fig. S3 shows negative shift of only $10 \mathrm{mV}$ in half-wave potential after 3000 cycles. These results demonstrated that $\mathrm{Pd} / \mathrm{O}-\mathrm{SiC}$ possessed better stability than the commercial Pt/C [59]. The outstanding durability of $\mathrm{Pd} / \mathrm{O}-\mathrm{SiC}$ might be related to the SMSIs between $\mathrm{Pd}$ and $\mathrm{SiC}_{x} \mathrm{O}_{y}$.

The adsorption of the key intermediate and the Gibbs free energy of the ORR pathway were investigated (Fig. 5) to reveal the underlying mechanism that improves the ORR performance of Pd/O-SiC than that of the commercial Pd/C. Figs. 5(a) and (b) show the stability structures of the $\mathrm{OOH}$ intermediate adsorbed on $\mathrm{Pd}_{4} / \mathrm{O}-\mathrm{SiC}$ and $\mathrm{Pd}_{4} / \mathrm{C}$. The adsorption energy of $\mathrm{OOH}$ on $\mathrm{Pd}_{4} / 0-\mathrm{SiC}(-2.13 \mathrm{eV})$ was higher than that on $\mathrm{Pd}_{4} / \mathrm{C}(-1.71 \mathrm{eV})$. The Gibbs free energy diagrams of the ORR of $\mathrm{Pd}_{4} / \mathrm{O}-\mathrm{SiC}$ and $\mathrm{Pd}_{4} / \mathrm{C}$ are shown in Fig. 5(c). At the equilibrium potential (1.23 $\mathrm{V}_{\mathrm{RHE}}$ ), the formation of $\mathrm{OOH}^{*}$ was an endergonic process, and the Gibbs free energies of $0^{*} \mathrm{H}^{*}$ formation on $\mathrm{Pd}_{4} / \mathrm{O}-\mathrm{SiC}$ and $\mathrm{Pd}_{4} / \mathrm{C}$ were 0.12 and $0.53 \mathrm{eV}$, respectively, indicating that $\mathrm{OOH}^{*}$ was easier to generate and more stable on $\mathrm{Pd}_{4} / \mathrm{O}-\mathrm{SiC}$ than on $\mathrm{Pd}_{4} / \mathrm{C}$. The reaction steps from $\mathrm{OOH}^{*}$ to $\mathrm{O}^{*}$ on $\mathrm{Pd}_{4} / \mathrm{O}-\mathrm{SiC}$ and $\mathrm{Pd}_{4} / \mathrm{C}$ were exergonic and facile to complete, and the Gibbs free energy of the step from $\mathrm{O}^{*}$ to $\mathrm{OH}^{*}$ on $\mathrm{Pd}_{4} / \mathrm{O}-\mathrm{SiC}$ was equal to that on $\mathrm{Pd}_{4} / \mathrm{C}$. Hence, $\mathrm{OOH}^{*}$ was the key ORR intermediate, and the better ORR performance of $\mathrm{Pd}_{4} / \mathrm{O}$-SiC compared to $\mathrm{Pd}_{4} / \mathrm{C}$ was related to the reduced Gibbs free energy.

To entirely avoid the surface oxidization of SiC during preparation, preservation, or application under aerobic conditions is difficult. Therefore, $\mathrm{Pd} / \mathrm{O}-\mathrm{SiC}$ and $\mathrm{Pd} / \mathrm{SiC}$ were compared using DFT calculations (Fig. 6) to further understand the role of oxidized SiC surface in enhancing the ORR performance of $\mathrm{Pd}$ NPs. The adsorption energy of the $\mathrm{Pd}_{4}$ cluster on $\mathrm{SiC}$ was higher than that on $\mathrm{O}-\mathrm{SiC}(-12.05 \mathrm{eV}$ vs. $-9.92 \mathrm{eV})$, and the electron transfer from $\mathrm{SiC}$ to the $\mathrm{Pd}_{4}$ cluster was more significant than that from 0-SiC $(-1.54$ e vs. -0.22 e) (Figs. 3(a), 3(c), and 6(a)-(b)). The reduction in charge transfer from O-SiC to the $\mathrm{Pd}_{4}$ cluster was ascribed to the strong electronegativity of oxygen. However, the adsorption energy of $\mathrm{OOH}^{*}$ on $\mathrm{Pd}_{4} / \mathrm{O}-\mathrm{SiC}$

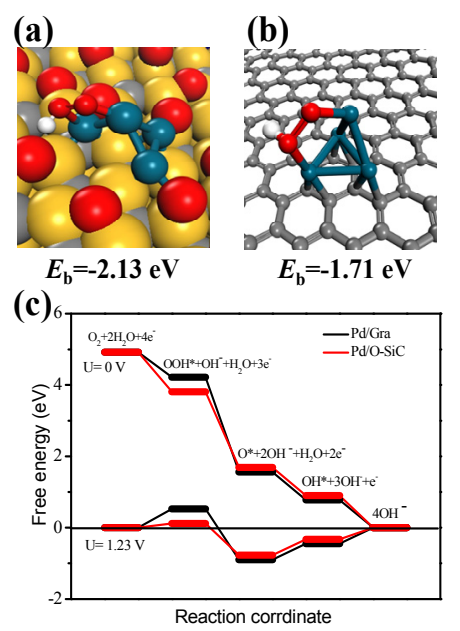

Fig. 5. Optimized structures and binding energies of $\mathrm{OOH}$ adsorbed on $\mathrm{Pd}_{4} / \mathrm{O}-\mathrm{SiC}$ (a) and $\mathrm{Pd}_{4} / \mathrm{C}$ (b); (c) Gibbs free energy diagrams of ORR over $\mathrm{Pd}_{4} / \mathrm{O}-\mathrm{SiC}$ and $\mathrm{Pd}_{4} / \mathrm{C}$.

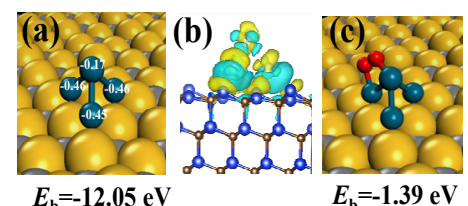

(d)

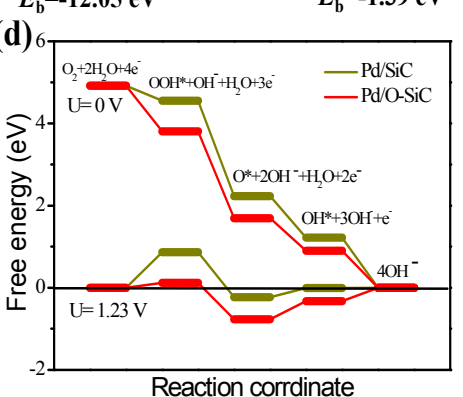

Fig. 6. DFT calculations of $\mathrm{Pd}_{4} / \mathrm{SiC}$. (a) Bader charge and binding energies of $\mathrm{Pd}_{4}$ supported on $\mathrm{SiC}$; (b) Charge density difference of $\mathrm{Pd}_{4} / \mathrm{SiC}$. Blue and yellow areas represent negative and positive charges, respectively; (c) Optimized structures and binding energies of $\mathrm{OOH}$ adsorbed on $\mathrm{Pd}_{4} / \mathrm{SiC}$; (d) Gibbs free energy diagrams of ORR over $\mathrm{Pd}_{4} / \mathrm{SiC}$ and $\mathrm{Pd}_{4} / \mathrm{O}-\mathrm{SiC}$.

$(-2.13 \mathrm{eV})$ was higher than that on $\mathrm{Pd}_{4} / \mathrm{SiC}(-1.39 \mathrm{eV})$, and the Gibbs free energy of $\mathrm{OOH}^{*}$ formation on $\mathrm{Pd}_{4} / \mathrm{O}-\mathrm{SiC}(0.12 \mathrm{eV})$ decreased on $\mathrm{Pd}_{4} / \mathrm{SiC}(0.86 \mathrm{eV}$ ) (Fig. 6(c)-(d)). The increased adsorption energy of the key intermediate $\mathrm{OOH}^{*}$ and the decreased Gibbs free energy of the crucial ORR step induced by the SiC surface oxidization enhanced the ORR performance [22].

\section{Conclusions}

Commercial $\mathrm{SiC}$ with $\mathrm{SiC}_{x} \mathrm{O}_{y}$ on its surface was used to support Pd NPs through a simple deposition precipitation method. Compared with commercial Pt/C, the prepared Pd/O-SiC catalyst had a better ORR activity with a positive shift of $10 \mathrm{mV}$ in the half-wave potential, superior stability with a lower current drop (3.5\% vs. $34.9 \%$ ) after $10 \mathrm{~h}$, and stronger resistance against methanol poisoning in $0.1 \mathrm{~mol} / \mathrm{L} \mathrm{KOH}$ electrolyte. The surface oxidization of $\mathrm{SiC}$ played a vital role in enhancing the ORR performance of the Pd NPs. Charge transfer from O-SiC to $\mathrm{Pd}$ resulted in electron-rich $\mathrm{Pd}$. The electronegative $\mathrm{Pd}$ increased the adsorption of the key intermediate $\mathrm{OOH}$ and decreased the Gibbs free energy of the key ORR step, thereby enhancing the ORR performance. This work provided an efficient strategy for the design and large-scale preparation of excellent Pd-based ORR electrocatalysts.

\section{Electronic supporting information}

Supporting information is available in the online version of this article.

\section{References}

[1] Y. G. Feng, Q. Shao, Y. J. Ji, X. N. Cui, Y. Y. Li, X. Zhu, X. Q. Huang, Sci. Adv., 2018, 4, 8817. 
[2] Q. Y. Yu, S. Yin, J. Zhang, H. M. Yin, Electrochim. Acta, 2019, 298, 599-608.

[3] W. Tamakloe, D. A. Agyeman, M. Park, J. Yang, Y. M. Kang, J. Mater. Chem. A, 2019, 7, 7396-7405.

[4] S. H. Zhang, X. T. Deng, A. J. Chen, H. K. Zhou, Z. Y. Xie, Y. L. Liang, F. H. Zeng, Int. J. Hydrogen Energy, 2019, 44, 21759-21768.

[5] J. Liu, M. Jiao, L. Lu, H. M. Barkholtz, Y. Li, Y. Wang, L. Jiang, Z. Wu, D. J. Liu, L. Zhuang, C. Ma, J. Zeng, B. Zhang, D. Su, P. Song, W. Xing, W. Xu, Y. Wang, Z. Jiang, G. Sun, Nat. Commun., 2017, 8, 15938.

[6] Z. F. Wu, D. Dang, X. L. Tian, ACS Appl. Mater. Interfaces, 2019, 11, 9117-9124.

[7] C. Y. Liu, E. Y. Li, ACS Appl. Mater. Interfaces, 2019, 11, 1638-1644.

[8] D. Wang, S. Liu, J. Wang, R. Lin, M. Kawasaki, E. Rus, K. E. Silberstein, M. A. Lowe, F. Lin, D. Nordlund, H. Liu, D. A. Muller, H. L. Xin, H. D. Abruna, Nat. Commun., 2016, 7, 11941.

[9] X. X. Wang, J. Sokolowski, H. Liu, G. Wu, Chin. J. Catal., 2020, 41, 739-755.

[10] E. Antolini, Energy Environ. Sci., 2009, 2, 915-931.

[11] J. C. C. Gomez, R. Moliner, M. J. Lazaro, Catalysts, 2016, 6, 130.

[12] Z. Y. Zhang, S. S. Liu, X. Tian, J. Wang, P. Xu, F. Xiao, S. Wang, J. Mater. Chem. A, 2017, 5, 10876-10884.

[13] W. P. Xiao, M. A. Liutheviciene Cordeiro, M. X. Gong, L. L. Han, J. Wang, C. Bian, J. Zhu, H. L. Xin, D. L. Wang, J. Mater. Chem. A, 2017, 5, 9867-9872.

[14] X. Z. Song, Q. Shi, H. Wang, S. L. Liu, C. Tai, Z. Y. Bian, Appl. Catal. B, 2017, 203, 442-451.

[15] G. W. Wang, J. X. Guan, L. Xiao, B. Huang, N. Wu, J. T. Lu, L. Zhuang, Nano Energy, 2016, 29, 268-274.

[16] M. V. Castegnaro, W. J. Paschoalino, M. R. Fernandes, B. Balke, M. C. M. Alves, E. A. Ticianelli, J. Morais, Langmuir, 2017, 33, 2734-2743.

[17] L. N. Sun, B. Y. Liao, X. Z. Ren, Y. L. Li, P. X. Zhang, L. B. Deng, Y. Gao, Electrochim. Acta, 2017, 235, 543-552.

[18] C. V. Tinoco-Munoz, J. L. Reyes-Rodriguez, D. Bahena-Uribe, M. A. Leyva, J. G. Cabanas-Moreno, O. Solorza-Feria, Int. J. Hydrogen Energy, 2016, 41, 23272-23280.

[19] M. Luo, Z. Zhao, Y. Zhang, Y. Sun, Y. Xing, F. Lv, Y. Yang, X. Zhang, S. Hwang, Y. Qin, J. Y. Ma, F. Lin, D. Su, G. Lu, S. Guo, Nature, 2019, 574, 81-85.

[20] Y. L. Li, W. H. Li, T. G. Ke, P. X. Zhang, X. Z. Ren, L. B. Deng, Electrochem. Commun., 2016, 69, 68-71.

[21] Z. K. Bao, H. Zhou, X. Song, Y. J. Gao, G. L. Zhuang, S. W. Deng, Z. Z. Wei, X. Zhong, J. G. Wang, ChemCatChem, 2019, 11, 1-9.

[22] J. Li, H. Zhou, H. Zhuo, Z. Wei, G. Zhuang, X. Zhong, S. Deng, X. Li, J.
Wang, J. Mater. Chem. A, 2018, 6, 2264-2272.

[23] L. X. Zuo, L. P. Jiang, J. J. Zhu, Ultrason. Sonochem., 2017, 35, 681-688.

[24] J. R. Zapata-Fernandez, Y. Gochi-Ponce, M. I. Salazar-Gastelum, E. A. Reynoso-Soto, F. Paraguay-Delgado, S. W. Lin, R. M. Felix-Navarro, Int. J. Hydrogen Energy, 2017, 42, 9806-9815.

[25] J. Stacy, Y. N. Regmi, B. Leonard, M. H. Fan, Renew. Sust. Energy Rev., 2017, 69, 401-414.

[26] H. Erikson, A. Sarapuu, J. Solla-Gullon, K. Tammeveski, J. Electroanal. Chem., 2016, 780, 327-336.

[27] X. Yang, Y. Zhang, Z. Fu, Z. Lu, X. Zhang, Y. Wang, Z. Yang, R. Wu, ACS Appl. Mater. Interfaces, 2020, 12, 28206-28216.

[28] M. Bhardwaj, H. Sharma, S. Paul, J. H. Clark, New J. Chem., 2016, 40, 4952-4961.

[29] J. Saha, K. Bhowmik, I. Das, G. De, Dalton Trans, 2014, 43, 13325-13332.

[30] Y. Takeda, M. Tamura, Y. Nakagawa, K. Okumura, K. Tomishige, ACS Catal., 2015, 5, 7034-7047.

[31] Z. L. Guo, Y. F. Liu, Y. Liu, W. Chu, Appl. Surf. Sci., 2018, 442, 736-741.

[32] S. Suzuki, T. Onodera, J. Kawaji, T. Mizukami, M. Morishima, K. Yamaga, J. Power Sources, 2013, 223, 79-85.

[33] S. M. Andersen, M. J. Larsen, J. Electroanal. Chem., 2017, 791, 175-184.

[34] R. Dhiman, S. N. Stamatin, S. M. Andersen, P. Morgen, E. M. Skou, J. Mater. Chem. A, 2013, 1, 15509-15516.

[35] R. Dhiman, E. Johnson, E. M. Skou, P. Morgen, S. M. Andersen, J. Mater. Chem. A, 2013, 1, 6030-6036.

[36] J. Su, Y. H. Wang, L. Dong, J. B. Zang, Chin. J. Inorg. Chem., 2018, 34, 1-10.

[37] J. Y. Li, J. Wang, D. F. Gao, X. Y. Li, S. Miao, G. X. Wang, X. H. Bao, Catal. Sci. Technol., 2016, 6, 2949-2954.

[38] Y. Zhang, J. B. Zang, L. Dong, X. Z. Cheng, Y. L. Zhao, Y. H. Wang, J. Mater. Chem. A, 2014, 2, 10146-10153.

[39] G. Q. Zhang, J. X. Peng, T. J. Sun, S. D. Wang, Chin. J. Catal., 2013, 34, 1745-1755.

[40] X. N. Guo, R. J. Shang, D. H. Wang, G. Q. Jin, X. Y. Guo, K. N. Tu, Nanoscale Res. Lett., 2010, 5, 332-337.

[41] L. Li, J. Zheng, Y. F. Liu, W. Wang, Q. S. Huang, W. Chu, ChemistrySelect, 2017, 2, 3750-3757.

[42] N. D. Shcherban, J. Ind. Eng. Chem., 2017, 50, 15-28.

[43] Y. Jiao, Y. Zheng, M. Jaroniec, S. Z. Qiao, J. Am. Chem. Soc., 2014, 136, 4394-4403.

[44] B. Delley, J. Chem. Phys., 2000, 113, 7756-7764.

[45] G. Kresse, D. Joubert, Phys. Rev. B, 1999, 59, 1758-1775.

\section{Graphical Abstract}

Chin. J. Catal., 2021, 42: 963-970 doi: 10.1016/S1872-2067(20)63716-0

Enhanced oxygen reduction reaction performance over Pd catalysts by oxygen-surface-modified $\mathrm{SiC}$

Jing Li, Xiang Sun, Yongzheng Duan, Dongmei Jia, Yuejin Li, Jianguo Wang* Binzhou University; Zhejiang University of Technology

Charge transfer from $\mathrm{SiC}_{x} \mathrm{O}_{y}$ on the surface of $\mathrm{SiC}$ to Pd NPs enhanced the ORR activity by inducing electron-rich Pd.

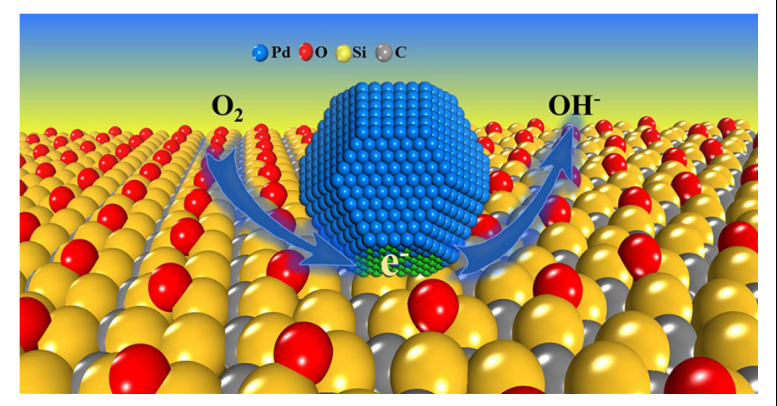


[46] J. P. Perdew, K. Burke, M. Ernzerhof, Phys. Rev. Lett., 1996, 77, 3865-3868.

[47] L. Dong, J. B. Zang, L. Su, Y. D. Jia, Y. H. Wang, J. Lu, X. P. Xu, Int. J. Hydrogen Energy, 2014, 39, 16310-16317.

[48] H. Zhou, B. Han, T. Liu, X. Zhong, G. Zhuang, J. Wang, Green Chem., 2017, 19, 3585-3594.

[49] Y. Li, C. Zhang, H. He, J. Zhang, M. Chen, Catal. Sci. Technol, 2016, 6, 2289-2295.

[50] Y. Zhang, G. Gajjala, T. Hofmann, L. Weinhardt, M. Bar, C. Heske, M. Seelmann-Eggebert, P. Meisen, J. Appl. Phys., 2010, 108, 093702.

[51] P. S. M. Kumar, V. K. Ponnusamy, K. R. Deepthi, G. Kumar, A. Pugazhendhi, H. Abe, S. Thiripuranthagan, U. Pal, S. K. Krishnan, J. Mater. Chem. A, 2018, 6, 23435-23444.

[52] Q. Yang, L. J. Shi, B. B. Yu, J. Xu, C. Wei, Y. W. Wang, H. Y. Chen, J. Mater. Chem. A, 2019, 7, 18846-18851.
[53] J. X. Mao, P. Liu, C. C. Du, D. X. Liang, J. Y. Yan, W. B. Song, J. Mater. Chem. A, 2019, 7, 8785-8789.

[54] Y. Hou, S. Cui, Z. Wen, X. Guo, X. Feng, J. Chen, Small, 2015, 11, 5940-5948.

[55] X. Zhou, Y. J. Gao, S. W. Deng, S. Cheng, S. H. Zhang, H. Hu, G. L. Zhuang, X. Zhong, J. G. Wang, Ind. Eng. Chem. Res., 2017, 56, 11100-11110.

[56] Y. Choi, D. Lim, E. Oh, C. Lim, S. H. Baeck, J. Mater. Chem. A, 2019, 7, 11659-11664.

[57] K. Li, M. L. Xiao, Z. Jin, J. B. Zhu, J. J. Ge, C. P. Liu, W. Xing, Electrochim. Acta, 2017, 235, 508-518.

[58] G. A. Ferrero, A. B. Fuertes, M. Sevilla, M.-M. Titirici, Carbon, 2016, 106, 179-187.

[59] J. N. Chen, X. L. Yuan, F. L. Lyu, Q. X. Zhong, H. C. Hu, Q. Pan, Q. Zhang, J. Mater. Chem. A, 2019, 7, 1281-1286.

\title{
部分氧化碳化硅提高钯催化氧还原反应性能
}

\author{
李 晶 ${ }^{\mathrm{a}}$, 孙 翔 ${ }^{\mathrm{b}}$, 段永正 ${ }^{\mathrm{a}}$, 贾冬梅, 李跃金 ${ }^{\mathrm{a}, \mathrm{b}}$, 王建国 ${ }^{\mathrm{b},{ }^{*}}$

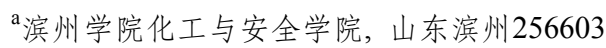

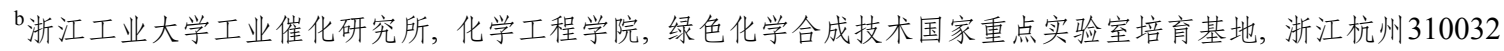

\begin{abstract}
摘要: 燃料电池具有能量转换效率高的优点, 是能量转换与储存的高效器件之一. 目前, 燃料电池阴极氧还原反应(ORR) 动力学缓慢, 并且催化ORR大量使用铂碳( $\mathrm{Pt} / \mathrm{C})$ 催化剂, 由于 $\mathrm{Pt}$ 储量少, 价格高, 载体碳材料易发生碳蚀导致催化剂稳定性 降低, 限制了其进一步商业化应用. 钯(Pd)与Pt为同族元素, 具有相似的电子结构和化学性质, 其储量是Pt的 50 倍, 同时, Pd 具有良好的抗甲醇毒性和抗一氧化碳毒性, 因此, 被视为燃料电池中阴极 Pt催化剂的潜在替代品. 但商用 $\mathrm{Pd} / \mathrm{C}$ 催化剂的 ORR活性较Pt/C差, 因此, 大量的研究工作集中在提高Pd基ORR催化剂的活性方面: 将Pd与具有 $3 d$ 轨道的金属形成合金或 将Pd负载到不同的载体上. 通过选择合适的载体影响Pd的电子结构, 从而提高催化剂活性和稳定性, 是一种较简单的、有 利于规模化生产Pd基ORR催化剂的方法.

碳化硅 $(\mathrm{SiC})$ 具有良好的电化学稳定性、热稳定性、机械强度和较强的供电子能力, 可被用作ORR的金属催化剂载体. 然而, 由于金属与 $\mathrm{SiC}$ 作用较弱, 需要制备特殊形貌的 $\mathrm{SiC}$ 或将 $\mathrm{SiC}$ 表面改性; 通常, 这些 $\mathrm{SiC}$ 基载体的制备过程复杂并且成本 高. 而在有氧条件下制备、保存或使用 $\mathrm{SiC}$ 时, 其表面不可避免地被氧化, 这种在温和条件下生成的表面具有含氧官能团的 $\mathrm{SiC}$, 由于制备过程简便, 可以大规模生产, 且与金属有强的相互作用, 是一种很有前景的ORR的Pd基催化剂载体. 对于用 于替代Pt基催化剂的负载型Pd基ORR催化剂的开发和大规模制造来说, 对载体表面改性的深入了解是一个重要并且具有 挑战性的课题. 目前尚未发现关于 $\mathrm{SiC}$ 表面的含氧基团对 $\mathrm{ORR}$ 性能影响的报道. 因此, 详细考察 $\mathrm{SiC}$ 载体上含氧基团在ORR 中的作用对于理解、设计和开发具有优异 $\mathrm{ORR}$ 性能的 $\mathrm{SiC}$ 负载催化剂至关重要.

本文采用沉积沉淀法在表面部分氧化的碳化硅 $(\mathrm{O}-\mathrm{SiC})$ 均匀负载了平均直径为 $5.2 \mathrm{~nm}$ 的 Pd纳米颗粒. 与 $20 \mathrm{wt} \%$ 商业 $\mathrm{Pt} / \mathrm{C}$ 相比, 制备的 $2.5 \mathrm{wt} \% \mathrm{Pd} / \mathrm{O}-\mathrm{SiC}$ 催化剂显示出较好的ORR活性(半波电位正向移动 $10 \mathrm{mV}$ ), 较好的稳定性 $(10 \mathrm{~h}$ 后, 电流密 度损失 $3.5 \%$ vs. $34.9 \%$ ), 和较高的抗甲醇毒性. 结构表征及密度泛函理论(DFT)计算结果表明, 与 $\mathrm{Pd} / \mathrm{C}$ 相比, Pd/O-SiC具有 优异的ORR 性能主要是由于 $\mathrm{O}-\mathrm{SiC}$ 载体对Pd纳米颗粒具有电子调控作用, 使Pd带负电. 富电子Pd增强了 ORR 关键中间体 $\mathrm{OOH}$ 的吸附, 降低了反应的吉布斯自由能, 从而提高了 ORR活性. 另外, O-SiC载体对Pd纳米颗粒具有大的结合能和较好的 $\mathrm{SiC}$ 稳定性, 增强了 $\mathrm{Pd} / \mathrm{O}-\mathrm{SiC}$ 催化剂的抗甲醇毒性及稳定性. DFT计算结果表明, $\mathrm{SiC}$ 表面部分氧化后, 仍保持对 $\mathrm{Pd}$ 的较高结 合能, 同时大幅增强了催化剂对中间体的吸附, 降低了 ORR 关键电化学步骤吉布斯自由能, 从而提高了氧还原性能. 因此, 本工作明确了 $\mathrm{SiC}$ 表面氧化的作用, 同时提供了一种简易大规模制备高效负载型铂基替代ORR催化剂的策略.
\end{abstract}

关键词: 碳化硅; 表面氧化; 氧还原反应; 密度泛函理论; 电荷转移; 富电钯

收稿日期: 2020-07-28. 接受日期: 2020-09-14. 上网日期: 2020-11-22.

*通讯联系人. 电话/传真: (0571)88871037; 电子信箱: jgw@zjut.edu.cn

基金来源：国家自然科学基金(51808040); 浙江省科技创新团队(2017R5203); 滨州学院科研基金(2019Y17).

本文的电子版全文由Elsevier出版社在ScienceDirect上出版(http://www.sciencedirect.com/science/journal/18722067). 